\title{
Risk Factors of Non-Communicable Diseases in a Frontier, Outermost, and Least Developed (3T) Archipelagic Region of Indonesia: a Community Study
}

\author{
Tiara Putri Leksono ${ }^{1}$, Auliana Ratri Prabandari Hidayat ${ }^{1}$, Fitrawan Silvano ${ }^{1}$, and Lutfan Lazuardi ${ }^{*}$ \\ ${ }^{1}$ Department of Medicine, Faculty of Medicine, Public Health and Nursing, Universitas Gadjah Mada, 55281 Yogyakarta, Indonesia \\ ${ }^{2}$ Department of Health Policy Management, Faculty of Medicine, Public Health and Nursing, Universitas Gadjah Mada, 55281 \\ Yogyakarta, Indonesia
}

\begin{abstract}
Health is a universal right for all mankind, including those living in Indonesia's Frontier, Outermost, and Least Developed areas also known as 3T Regions. Ilngei and Kabiarat Villages, which were the locations of our community study, are one of the villages belong to such regions of Western Southeast Maluku Regency — or Tanimbar Islands. In addition to difficulty of achieving equitable health workers and facilities distribution, indigenous people have also been found to live some unhealthy lifestyles including routine consumption of local made alcohol beverages known as sopi and smoking habits. This situation could be a risk factor for non-communicable diseases (NCD) such as hypertension, diabetes mellitus (DM), and high blood cholesterol. Therefore, our KKN-PPM UGM team conducted a community service activity in form of a free health check-up. This activity was aimed to screen health conditions particularly exploring NCDs risk factors, increase public awareness of health, and provide a reference for further health interventions and researches in this area. This research is an observational descriptive study, with primary data obtained during health check-up. The health check-up was carried out separately in two villages respectively on January 18th and 25th, 2020. Participants were recruited with purposive sampling, through invitation determined by the team. We used a digital blood pressure monitor to measure blood pressure and automatic skin-prick test device to measure capillary random blood sugar and total cholesterol level. Out of 102 participants, those classified as pre-hypertension were 33 people $(32.35 \%)$, stage I hypertension were 22 people $(21.56 \%)$, stage II hypertension were 32 people $(31.37 \%)$, uncertain DM were 55 people $(57.89 \%)$, DM were 4 people $(4.21 \%)$, borderline high total cholesterol level were 13 people $(20.31 \%)$, and high total cholesterol level was 1 person $(1.56 \%)$. Overall, the majority of participants had blood pressure and blood sugar level above the normal range. This kind of activity should be made on a regular basis to reach more number of participants and more detail information regarding NCDs risk factors.
\end{abstract}

KEYWORDS community study, non-communicable diseases, health check-up, 3T region

\section{Introduction}

Ilngei and Kabiarat Villages are one of the villages in South Tanimbar District, Western Southeast Maluku Regency (or Tanimbar Islands), Maluku Province, Indonesia. Western Southeast Maluku Regency is one of the frontier, outermost, and least developed area (also known as Terdepan, Terluar, dan Tertinggal or 3T Regions) of Indonesia [1]. Due to its geographical distance from the capital of province, coupled with its archipelagic arrangement, this regency is associated with difficult access and finds obstacles in form of education, economic growth, thus negatively impact its infrastructure development. The National Statistics
Agency (BPS) noted that Maluku Province was the third poorest province in Indonesia at 2010 based on a basic needs approach [2]. Moreover, health conditions in Ilngei and Kabiarat villages rarely received any attention from the central government of the country.

Indonesia's health problems have now shifted to non-communicable diseases (NCDs), although the trend of infectious diseases is still high [3]. NCDs contribute to a mortality rate of up to $73 \%$ in Indonesia [4]. The highest increases in risk factors are high blood pressure, high cholesterol, overweight, and smoking habits [3]. The Indonesian Ministry of Health recommends promotive and preventive activities in all areas of

\footnotetext{
* Corresponding author: lutfan.lazuardi@ugm.ac.id
} 
Indonesia, aimed to increase public awareness of NCDs and early detection of NCDs risk factors.

Therefore, we as a group of students conducting a community service activity-known as Kuliah Kerja Nyata Pembelajaran Pemberdayaan Masyarakat Universitas Gadjah Mada (KKN-PPM UGM) 4th period of 2019/2020, did a program aimed for an early detection of NCDs risk factors and also raise awareness of health conditions to the people of Ilngei and Kabiarat Villages. Free health check-up that included measurement of blood pressure, blood sugar level, and cholesterol level was expected to make indigenous people more aware and maintain their own condition for a healthier Indonesia, and provide data collections beneficial as a reference for health intervention or research activities that might be held in the future.

\section{Methods}

The methods we used in the health check-up activity were measurement of blood pressure, blood sugar level, and cholesterol level. After the measurement, results interpretations were explained to the participants. Our research is an observational descriptive study, with primary data obtained during health check-up.

\subsection{Sample Selection}

This study used purposive sampling. Participants were 42 people from Ilngei Village and 60 people from Kabiarat Village who had been determined by the team of KKN-PPM UGM. Participants were invited to attend a free health check-up and NCDs risk factors detection. A purposive sample--also called judgment, selective or subjective sampling, is a method of sampling technique in which the researcher relies on the judgment of the researcher when choosing a sample to participate in the study. Inclusion criteria were the residents of Kabiarat Village and Ilngei Village; adults ( $\geq 18$ yo) with three age classifications (Adults 18-35 years old, middle-age adults 36-55 years old, and older adults $>55$ years old) [20]; able to communicate; and have willingness to participate in health check-up. Meanwhile, the exclusion criterion was the residents who were not in place when the health check-up was held.

\subsection{Location, time, and duration of activity}

The first activity was held on January 18th, 2020 at the Puskesmas Pembantu or Pustu (Auxilliary Primary Healthcare) of Ilngei Village with duration of 4 hours (09.00 a.m.-01.00 p.m., GMT+9) and the second was held on January 25th, 2020 at the Pos Kesehatan Desa or POSKESDES (Village Healthcare) of Kabiarat Village with duration of 6 hours (01.00 p.m.-07.00 p.m., GMT+9). The two villages belong to the South Tanimbar District, Western Southeast Maluku Regency or Tanimbar Islands, Maluku Province, Indonesia.

\subsection{Data collection techniques and data analysis techniques}

The data was obtained from the results of health checkup by our team in Ilngei and Kabiarat Village, then the data was categorized. Blood pressure was classified into 5 categories: normal with systolic pressure $<120 \mathrm{mmHg}$ and diastolic $<80 \mathrm{mmHg}$, pre-hypertension with systolic pressure of $120-139 \mathrm{mmHg}$ or diastolic $80-89 \mathrm{mmHg}$, stage I hypertension with systolic pressure of 140-159 $\mathrm{mmHg}$ or diastolic $90-99 \mathrm{mmHg}$, and hypertension stage II with systolic pressure of $>160 \mathrm{mmHg}$ or diastolic $>100 \mathrm{mmHg}$ [7]. Random capillary blood sugar level was classified into 3 categories: non-DM with levels <90 mg / dl, uncertain DM with levels of 90-199 $\mathrm{mg} / \mathrm{dl}$, and DM with $\geq 200 \mathrm{mg} / \mathrm{dl}$ [8]. Total cholesterol level was classified into 3 categories: normal if less than $200 \mathrm{mg} / \mathrm{dL}$, high borderline if $200-239 \mathrm{mg} / \mathrm{dL}$, and high if $\geq 240 \mathrm{mg} / \mathrm{dL}$ [9].

\section{Results}

The health check-up and NCDs risk factors screening program was carried out in 2 days, with a total of 102 participants. The majority of the subjects were female $(71.6 \%)$ and most subjects were $>55$ years old $(42.2 \%)$ as shown in Table 1.

Table 1. Participants Characteristics

\begin{tabular}{lcc}
\hline \multicolumn{1}{c}{ Variable } & n & \% \\
\hline Sex & & \\
Male & 29 & 28.4 \\
Female & 73 & 71.6 \\
\hline Age & & \\
Adults (18-35 years old) & 20 & 19.6 \\
Middle-age adults (36-55 & 39 & 38.2 \\
years old) & 43 & 42.2 \\
Older adults (>55 years old) & 4 \\
\hline
\end{tabular}

The people of Ilngei and Kabiarat Village seemed enthusiastic to join the program as shown in Figure 1 and Figure 2.

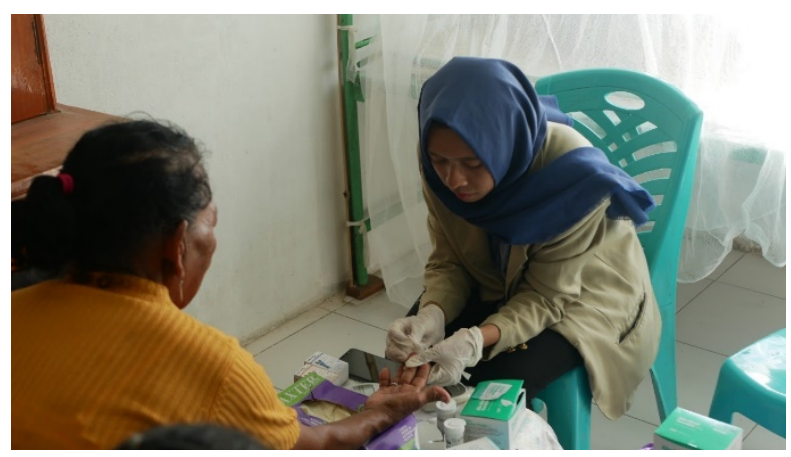

Fig. 1. Health check-up in Ilngei Village 


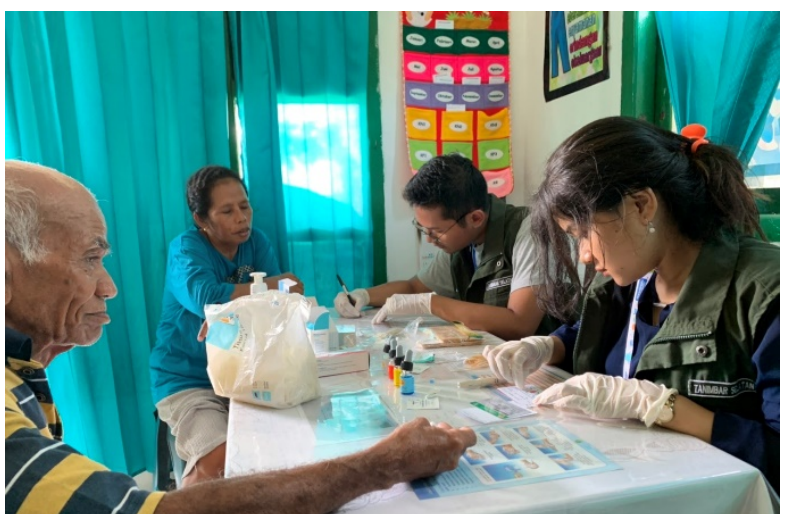

Fig. 2. Health check-up in Kabiarat Village

Based on the results of the examination in Table 2 below, it was found that out of all 102 participants attending the health check-up, the number of participants classified into normal blood pressure were 15 people $(14.71 \%)$, pre-hypertension were 33 people $(32.35 \%)$, stage I hypertension were 22 people $(21.56 \%)$, and stage II hypertension were 32 people $(31.37 \%)$

Table 2. Results of blood pressure measurement, $n=$ number of participants

\begin{tabular}{|c|c|}
\hline $\begin{array}{c}\text { Classification of } \\
\text { Blood Pressure }\end{array}$ & $\mathbf{n = 1 0 2}$ \\
\hline Normal & $25(14.71 \%)$ \\
\hline Pre-Hypertension & $33(32.35 \%)$ \\
\hline $\begin{array}{c}\text { Hypertension } \\
\text { Stage I }\end{array}$ & $22(21.56 \%)$ \\
\hline $\begin{array}{c}\text { Hypertension } \\
\text { Stage II }\end{array}$ & $32(31.37 \%)$ \\
\hline
\end{tabular}

On the D-Day of the program, blood sugar level measurement was carried out for all participants willing to be examined. We were using random capillary blood samples, so participants did not need to fast the night before. From the results of Table 3 below, it could be found that the number of participants classified as nonDM were 36 people (37.89\%), uncertain DM were 55 people $(57.89 \%)$, and DM were 4 people $(4.21 \%)$.

Table 3. Results of random capillary blood glucose level measurement, $n=$ number of participants

\begin{tabular}{|c|c|}
\hline $\begin{array}{c}\text { Classification of } \\
\text { Blood Sugar Level }\end{array}$ & $\mathbf{n = 9 5}$ \\
\hline Non-DM & $36(37.89 \%)$ \\
\hline
\end{tabular}

\begin{tabular}{|c|c|}
\hline Uncertain DM & $55(57.89 \%)$ \\
\hline DM & $4(4.21 \%)$ \\
\hline
\end{tabular}

Meanwhile, the total cholesterol level measurement was carried out on participants with $\geq 2$ positive (yes) answers from the following 4 questions: 1) Do you have chest pain upon a physical activity? 2) Do you often eat red meat/fatty foods/oily foods? 3) Is your blood pressure more than 140/90? 4) Are you more than 55 years old? Thus, based on the following Table 4, it could be found that the number of participants classified as normal were 50 people $(78.13 \%)$, high borderline were 13 people (20.31\%), and high was 1 person $(1.56 \%)$.

Table 4. Results of total cholesterol level measurement, $n=$ number of participants

\begin{tabular}{|c|c|}
\hline $\begin{array}{c}\text { Classification of } \\
\text { Cholesterol Level }\end{array}$ & $\mathbf{n = 9 5}$ \\
\hline Normal & $50(78.13 \%)$ \\
\hline Borderline & $13(20.31 \%)$ \\
\hline High & $1(1.56 \%)$ \\
\hline
\end{tabular}

\section{Discussion}

Non-communicable diseases (NCDs) are the leading cause of death globally, and one of the main health challenges in the 21st century [4]. NCDs consists of cardiovascular disease (stroke, coronary heart disease), diabetes, musculoskeletal / arthritis, cancer, and so on [11]. Metabolic risk factors that contribute to the development of NCDs include increased blood glucose level, blood pressure, and blood cholesterol level [11]. Hypertension is the third highest disease suffered by the people of Tanimbar Islands Regency, with 5,809 people in 2018 [12]. In addition, there was also an increase in the number of people with diabetes mellitus (DM) in the population aged >15 years from 20132018 in the Province of Maluku [13].

The results of this study showed participants classified as pre-hypertension were 33 people $(32.35 \%)$, stage 1 hypertension 22 people $(21.56 \%)$, stage 2 hypertension 32 people $(31.37 \%)$, uncertain DM were 55 people $(57.89 \%)$, DM were 4 people $(4.21 \%)$, borderline high cholesterol were 13 people $(20.31 \%)$, and high cholesterol was 1 person (1.56\%). Some factors that can contribute to these conditions include unhealthy lifestyles, low level of education, lack of health workers and health care facilities, lack of public awareness for health, and low socioeconomic status. 
The high number of people with blood pressure above the normal range can be related to unhealthy lifestyles such as routine alcohol consumption and smoking habits. Maluku people especially in Western Southeast Maluku, have a habit of consuming alcohol, which according to the local language is called 'sopi'. Sopi is a Maluku's traditional beverage containing alcohol above 50\%, making it to the category of liquor group C. It is presented at many traditional ceremonies or parties. Even in daily life, sopi is almost always present in the middle of Maluku society [14]. Alcohol consumption was known to be able to trigger cardiovascular disease, including hypertension, haemorrhagic stroke, and atrial fibrillation [15].

An increase in blood pressure can also be caused by smoking habits that still occur in many parts of the community. About one third of Western Southeast Maluku people's weekly income is allocated for the needs of household's heads who consume cigarettes [2]. A lot of evidence supports the conclusion that smoking can cause hypertension and dyslipidaemia thereby increasing the risk of coronary heart disease [17]. In addition, smoking is an independent risk factor for diabetes, and it has been estimated that $12 \%$ of the incidence of diabetes in the United States is caused by smoking [16].

From the aspect of education, most of the people in Tanimbar Islands are high-school graduates, and the second most are elementary-school graduates [10]. Health outcomes are closely related to education levels. Lower education level have been found related to the incidence and higher prevalence of NCDs, as it affects people's awareness on the importance of health [18].

In addition to low public awareness towards health condition, health facilities and health workers in Ilngei and Kabiarat Village are also still lacking. In 2018, there was 1 auxiliary primary health care known as Pustu (Puskesmas Pembantu) in Ilngei Village and none in Kabiarat Village, but the Pustu did not have any medical doctor. Meanwhile, in South Tanimbar District, there were 1 primary health care and 3 hospitals, and overall in 2018 it only had 3 general practitioners and 27 general nurses per 38,880 population [10]. It was far below the standard of national health authorities as stated in KEPMENKES No. 81 Year 2004, which targeting by the year of 2019 there were at least 96 general practitioners and 158 nurses per 100,000 population [11]. This certainly has an impact on the quality of health services in Ilngei and Kabiarat Village as a whole. The NCDs service standards would also be difficult to achieve, as the patients with such diseases require periodic control to the health care facility.

The socioeconomic conditions in Ilngei and Kabiarat villages are also considered alarming. The majority of the population work in agriculture and fisheries sectors yielding a fluctuated daily income. In $2019,27.25 \%$ of the population in the Tanimbar Islands Regency were classified as poor [12]. The low socioeconomic conditions affect several lifestyles such as smoking habits, difficulty in fulfilling nutritious food needs, and stressful thoughts related to income and work instability that have an impact on increasing the risk of NCDs. This is consistent with studies in Iran which show that people with low economic status are more at risk of contracting NCDs [19].

The strength of this study is that we were able to reach the people living in one of the $3 \mathrm{~T}$ regions of Indonesia, and were able to take samples and produce primary numerical data. The limitation of this study is that some NCDs risk factors exploration were not carried out individually at the same time of health checkup, so we used secondary data on socio-demographic conditions to elaborate the current condition.

\section{Conclusion}

The prevalence of Ilngei and Kabiarat Villages residents with blood pressure and blood glucose level above the normal range is high. As explained by secondary data from previous studies and our own observation on local people's daily life, possible risk factors for this condition include unhealthy lifestyles, low education, lack of health workers and health care facilities, lack of awareness towards health, and low socioeconomic conditions.

Further research is needed to evaluate the impact of NCDs risk factors on the complications of cardiovascular diseases. We also recommend similar health screening activities to be conducted regularly, thus more people could feel the impact. In addition, our study can be used as a reference for conducting another health research and interventions that are able to explore NCDs risk factors more comprehensively, with more number of respondents reaching more districts and villages in the Western Southeast Maluku Regency.

The authors would like to thank all those who have assisted the process of accomplishing the research, especially to the DPKM UGM, Government of the Western Southeast Maluku Regency, Department of Health of the Western Southeast Maluku Regency, Head of South Tanimbar District, Head of Ilngei Village, Head of Kabiarat Village, health cadres of Ilngei and Kabiarat Villages, all group members of KKN-PPM UGM Tanimbar Selatan 2019/2020, and all participants who were willing to be involved.

The authors declared no potential conflict of interest with respect to the research, authorship, and/or publication of this article.

\section{References}

1. Peraturan Badan Nasional Pengelola Perbatasan nomor 1 tahun 2015 tentang rencana induk pengelolaan perbatasan negara tahun 2015-2019. 2015.

2. Soselisa H, Sihasale W, Soselisa P, Litaay S. Masyarakat Pesisir di Kabupaten Maluku 
Tenggara Barat [Internet]. Diktas.iwlearn.org. 2011 [cited 6 July 2020]. Available from: http://diktas.iwlearn.org/atsea/publication1/masyarakat-pesisir-di-kabupaten-malukutenggara-barat

3. Mahendradhata Y, Trisnantoro L, Listyadewi S, Soewondo P, Marthias T, Harimurti P et al. Health System in Transition. The Republic of Indonesia Health System Review. 2017;7(1):xxvii-xxviii.

4. Non communicable diseases [Internet]. Who.int. 2020. [cited 6 July 2020] Available from: $\quad$ https://www.who.int/en/newsroom/fact-sheets/detail/noncommunicablediseases

5. Purposive sampling [Internet]. ResearchMethodology. 2020 [cited 6 July 2020]. Available from: https://researchmethodology.net/sampling-in-primary-datacollection/purposive-sampling/

6. Indonesia | Factsheets | Youthpolicy.org [Internet]. Youthpolicy.org. 2014 [cited 6 July 2020]. Available from: https://www.youthpolicy.org/factsheets/countr y/indonesia/

7. The Seventh Report of the Joint National Committee on Prevention, Detection, Evaluation, and Treatment of High Blood Pressure: the JNC 7 Report-Correction. JAMA. [Internet]. 2003 [cited 6 July 2020];290(2):197. Available from https://www.nhlbi.nih.gov/files/docs/guideline s/jnc7full.pdf doi: 10.1001/jama.290.2.197.

8. Perkumpulan Endokrinologi Indonesia (PERKENI), Pengelolaan dan Pencegahan Diabetes Melitus Tipe 2 di Indonesia. 2015. Available from: https://pbperkeni.or.id/wpcontent/uploads/2019/01/4.-KonsensusPengelolaan-dan-Pencegahan-Diabetesmelitus-tipe-2-di-Indonesia-PERKENI2015.pdf [cited 6 July 2020].

9. Expert Panel on Detection, Evaluation, and Treatment of High Blood Cholesterol in Adults. Executive Summary of the Third Report of the National Cholesterol Education Program (NCEP) Expert Panel on Detection, Evaluation, and Treatment of High Blood Cholesterol in Adults (Adult Treatment Panel III). JAMA: The Journal of the American Medical Association [Internet]. 2001;285(19):2486-2497. Available from: https://www.ahajournals.org/doi/10.1161/circ. 106.25.3143

10. Badan Pusat Statistik Kabupaten Kepulauan Tanimbar. Kecamatan Tanimbar Selatan dalam Angka 2019. Maluku Tenggara Barat: BPS Kabupaten Maluku Tenggara Barat; 2019.

11. Pemerintah Indonesia. Rancangan 5 September 2011: Rencana pengembangan tenaga kesehatan tahun 2011 - 2025. Jakarta: Pemerintah Indonesia; 2011.

12. Badan Pusat Statistik Kabupaten Kepulauan Tanimbar. Kabupaten Kepulauan Tanimbar dalam Angka 2020. Maluku Tenggara Barat: BPS Kabupaten Maluku Tenggara Barat; 2020.

13. Pusat Data dan Informasi Kementrian Kesehatan RI, Hari Diabetes Sedunia Tahun 2018. 2019. Available from file://D:/FK\%20UGM/Publikasi/infodatinDiabetes-2018.pdf

14. Tuti B, Jeanny FM, Aswin B. Studi Pemetaan Sosial Dan Penyusunan Corporate Social Responsibility (CSR) Master Plan Terminal BBM Jayapura. Makassar: Kedai Buku Jenny; 2015 Available from https://docplayer.info/49451513-Studipemetaan-sosial-dan-penyusunan-corporatesocial-responsibility-csr-master-plan-terminalbbm-saumlaki.html

15. Parry CD, Patra J, Rehm J. Alcohol consumption and non-communicable diseases: epidemiology and policy implications. Addiction [Internet]. 2011 Oct [cited 6 July 2020];106(10):1718-24. Available from https:/www.ncbi.nlm.nih.gov/pmc/articles/P MC3174337/ doi: 10.1111/j.13600443.2011.03605.x. PMID: 21819471; PMCID: PMC3174337.

16. Thakur JS, Garg R, Narain JP, Menabde N. Tobacco use: a major risk factor for non communicable diseases in South-East Asia region. Indian J Public Health [Internet]. 2011 Jul-Sep [cited 6 July 2020]; 55(3):155-60. Available from https://pubmed.ncbi.nlm.nih.gov/11230269/ https:/pubmed.ncbi.nlm.nih.gov/22089682/\#: $\sim:$ text $=$ Out $\% 20$ of $\% 205.1 \% 20$ millions $\% 20$ tob acco,physical $\% 20$ activity $\% 20$ for $\% 20$ preventi ng\%20NCDs. doi: 10.4103/0019-557X.89943.

17. Primatesta P, Falaschetti E, Gupta S, Marmot MG, Poulter NR. Association between smoking and blood pressure: evidence from the health survey for England. Hypertension [Internet]. 2001 Feb [cited 6 July 2020];37(2):187-93. Available from doi: 10.1161/01.hyp.37.2.187

18. Dalstra JA, Kunst AE, Borrell C, Breeze E, Cambois E, Costa G, Geurts JJ, Lahelma E, Van Oyen H, Rasmussen NK, Regidor E, Spadea T, Mackenbach JP. Socioeconomic differences in the prevalence of common chronic diseases: an overview of eight European countries. Int J Epidemiol [Internet]. 2005 Apr [cited 6 July 2020];34(2):316-26. Available from https://pubmed.ncbi.nlm.nih.gov/15737978/ doi: 10.1093/ije/dyh386. Epub 2005 Feb 28. PMID: 15737978. 
19. Tol A, Sharifirad G, Shojaezadeh D, Tavasoli E, Azadbakht L. Socio-economic factors and diabetes consequences among patients with type 2 diabetes. J Educ Health Promot [Internet]. 2013 Feb [cited 6 July 2020]; 28;2:12. Available from https://www.ncbi.nlm.nih.gov/pmc/articles/P MC3778578/\#: : :text=In\%20type \%2D2\%20di abetic\%20patients,related $\% 20$ to $\% 20$ socio $\% 2$ Deconomic\%20status. doi: 10.4103/22779531.108009.

20. Petry NM. A comparison of young, middleaged, and older adult treatment-seeking pathological gamblers. Gerontologist [Internet]. 2002 Feb [cited 25 September 2020];42(1):92-9. Available from https://pubmed.ncbi.nlm.nih.gov/11815703/ doi: 10.1093/geront/42.1.92. PMID: 11815703. 